\title{
Eurocentrism and the Historical Perception About the Malays
}

\author{
Azmi Arifin ${ }^{1}$ \\ ${ }^{1}$ Senior Lecturer, History Section, School of Humanities, Universiti Sains Malaysia, Penang Malaysia.
}

\begin{abstract}
This study examines the effects of Eurocentrism to the view of the character, nature and image of the Malays especially in the period of British colonialism in the 19th century. This research explains why Eurocentrism creates confusing and negative views of the nature, civilisation and wisdom of the indigenous people. Eurocentrism is a form of thoughts that often measures and defines non-European civilisation through historical, cultural, religious, geographical, scientific and progressive perspectives based on Western or European values, which is considered to be supreme. The beliefs transpired in the minds of scholars and European politicians as early as the 16th century, and some were extended in the writings about local history by means of the roles played by the European colonial explorers and administrators. In the process of colonising and exploiting the wealth of the indigenous people, the European explorers and administrators often created records that could explain not only the economic potentials of the area that they intend to colonise, but also depicted the inferior characteristics and civilisations of that society to justify their colonisation attempts. In the process, they produced a record of colonial history which later became key references to historians to understand and explain the traits of the indigenous peoples. The ideas behind that colonial history were not only biased as the result of exaggerating the ignorance and retrogression of the indigenous people; it even sought to undermine the wisdom and civilisation of the indigenous people. This is to highlight their own superiority and noble values when placed side by side with the values of the indigenous people. Despite the prejudice, the Eurocentric colonial history is very influential in Malaysia's historiography until this day. This study explains how the influence of thoughts has blurred the understanding of the actual traits of the indigenous peoples and create an apparent confusion over the history of Malay society.
\end{abstract}

\section{Introduction}

This writing examines a form of thought, belief or prejudice known as Eurocentrism that strongly influences the historical interpretations of the Malays until now. The main purpose of this study is to explain how embracing these thoughts and prejudices have dictated the historical interpretations of the characteristics, practice and the political knowledge of the Malay society before and under the British colonialism. The study focuses on the historiographical traits of political institutions and the pattern of governance in the Malay states within the Malay Peninsula before the arrival of British colonialization which began with the Pangkor Treaty in 1874.

The influence of Eurocentrism on Malay politics is rarely discussed. Therefore, many scholars are unaware of their existence or understand its true influence on the interpretation of Malay political history about the Malay states. Instead, local historians, until now, are generally more inclined to take on any concept that the Europeans have introduced to explain the early political nature of the Malays. Full reliance on the European concepts and colonial references cause the explanation given about the traits and practices of the indigenous community to be misrepresented. They are often not based on the actual knowledge and the true nature of the indigenous society, but rather as a reflection or comparison of the differences in values between the Malay and European civilisation. In reality, the images and concepts brought into Malay political historiography are more of a picture based on the perception and prejudiced thoughts of the Europeans about the Malays. They are not a comprehensive and empirical study of the true nature of the indigenous community itself. As a result, the historiography that deals with the political

\footnotetext{
${ }^{1}$ Corresponding author: azmiarifin@usm.my
} 
characteristics of the indigenous people today is not an entirely true representation of the indigenous history, but rather a historical recollection seen from the eyes of the Europeans (Tregonning, 1958; Goh, 2007).

\section{Eurocentrism in Historical Thoughts}

According to Blaut (1993:1), Eurocentrism or Eurocentric diffusionism is a form of thought that strongly believes that Europe is a centre of civilisation excellence and it drives human progress either in specific locations or around the world. This theory or thinking explains how progress or civilisation moves and evolves from one centre to another. The ultimate centre of civilisation is considered the reason for the spread of civilisation to other parts of the world that are considered far more backwards and inferior. In this context, Europe is seen as a centre that triggers, propagates and develops all other civilisations. Therefore, it operates as a historical creator, while non-Europe only makes progress as an imitator and recipient of the European civilisation (Blaut, 1993: 1).

Europeans are seen as the "makers of history". Europe eternally advances, progresses, modernize. The rest of the world advances more sluggishly, or stagnates: it is a "traditional society". Therefore, the world has a permanent geographical center and a permanent periphery: an Inside and an Outside. Inside leads, Outside lags. Inside innovates, Outsides Imitates ... Europe, eternally, is Inside. Non-Europe is Outside. Europe is the source of most diffusions; Non-Europe is the recipient.

Blaut emphasized the difference between the true nature of European progress and myths, assumptions and perceptions, deliberately designed and exaggerated, aimed at creating the wrong view about European excellence against the inferiority of others. These myth, assumptions and perceptions are formed without objective, scientific or evidencebased research. According to Blaut (2000:4):

I use Eurocentrism to indicate false claims by Europeans that their society or region is, or was in the past, or always has been and always will be, superior to other societies or regions. The key word here is "false". It is not Eurocentric to prefer European music to other music, or European cuisine to another cuisine. It is Eurocentric to make the claim that Europeans are more inventive, innovative, progressive, noble, courageous, and so on than every other group of people; Or that Europe as a place as a more healthy, productive, stimulating environment than other places. It is not Eurocentric to extol "England's green and pleasant land", but it is Eurocentric to claim that this land is greener and more pleasant than all other lands of the world.

According to him, Eurocentrism is a form of European-focused thinking, which evaluates and makes a comparison between a non-European civilisation with Europe, based on false assumptions. It even aims at creating contempt, by trying to show Europe as more noble, superior, intelligent, powerful, advanced, astute, and supreme compared to nonEuropeans. For example, the European political system which is a form of democracy, is regarded as the ultimate political system in contrast to the political system of the non-Europeans, such as those based on Hinduism or Islam, or the climate and physical geography of Europe are the best compared to the climate and the physical lay-out of Asia, or the Europeans as humans are far more civilized and distinguished compared to the indigenous people of Africa, India or South America, or the European culture is more noble and outstanding than non-European culture (Amin, 1989; Quijano and Ennis, 2000: 533-80; Lander, 2000: 519-32; Alatas, 2001: 49-67; S. Sayyid, 2007: 300-16; Hobson, 2009: 217-38; Forstater. 2009: 63-76; Majid Amini, 2010: 29-45;).

The idea that elevates Europe as more noble and superior than non-Europeans emerged in the thoughts of Europeans since $16^{\text {th }}$ immemorial, but it became so significant at the end of the 19th century. This is because such thoughts have been driven by the emergence of the ideology of colonialism, racism and the theory of social evolution that grew rapidly in Europe, particularly in Britain during that period. During that period, there were two important developments that strengthened Eurocentrism (Azmi Arifin, 2007; Chapter 2). First, the emergence of the social evolution theory and theory of progress (the idea of progress) brought about by well-known European thinkers such as Montesquieu, Voltaire, Hegel, Marx, Spencer and Darwin. They claimed that the level of human progress and change could only be measured through the hierarchy of progress accomplished by Europe, and cultures that are far apart from it (to be called primitive or Asiatic) are the most inferior civilisation. Therefore, the European thinkers deemed some of the non- 
European worlds as the missing link to the point that they equate Africans and Southeast Asians as apes, chimpanzee or Orang Utan (Steadman, 1969; Marshall and Williams, 1982; Savage, 1984; Miles, 1989).

Second, the development of imperialism witnessed the opening of many new colonies and the widespread expansions of new myths about the violence and the inferiority of the Asian civilisation. Reports submitted by colonial explorers and administrators about despotism and feudalism in Southeast Asia, for example, have been extensively misrepresented as justification to reinforce the European perceptions about their advancement and the decline of nonEuropean societies, which were then considered to experience the stages of stagnation in European history. Therefore, the uneducated and backwards Asian people who were equated to slaves seen in the days of European feudalism who deserved to be treated with contempt in the name of progress and enlightenment (Savage, 1984).

The political and economic domination of the non-European world through the success of military and colonial expeditions had created a perception of Europe's greatness vis-à-vis the inferiority and retrogression of the nonEuropeans. In the process of distinguishing themselves from the colonised natives, the Europeans such as the British, often make notes of their superiority and their virtuousness so a comparison could be made about the inferiority of the indigenous people whom they called Asiatic-feudalists. Among the notes made included reinterpreting the progress of the indigenous history according to the 'tunnel' or 'hierarchy' of the European historical progress, based on the historical phases experienced by the Europeans. This situation had influenced the formation of a historical interpretation grounded in the theory of social evolution; a belief that since the European civilization is the best, then the whole nonEuropean world needs to go through the same historical stages as those experienced by the Europeans in order to make progress, with the European being seen as the ultimate race of the highest level or hierarchy. The deduction was often made that Europe had already undergone various historical stages which included the primitive, slavery, feudal and capitalist age, and in the 19th century moving towards the age of transition, also known as the industrial age or modern age. Hence, occupied colonies which had not gone through similar phases were considered backwards and left behind; they were believed to be at the lowest level of the European history, known as the Asiatic, Slave or Feudal times (Azmi, 2007: Chapter 2).

Imperialism in Asia and Southeast Asia had allowed the Europeans to assert their belief in superiority; thus, confidently and fully utilising the ideology of Eurocentrism to whiten their exploitation policies. Indeed, by depicting the indigenous people of Asia and Africa as those from an inferior civilisation, European colonialism was successful in asserting the myth of white man's burden in order to uphold the assumption that non-civilized and non-European natives should be colonized for the sake of civilisation, and that the holy duty was determined by God only for the greatest nation. As such, British colonialism is, for example, regarded as a process of civilisation and enlightenment of non-Europeans as opposed to other forms of colonialism that were driven by the intention to oppress and exploit (e.g. Japanese colonialism). As explained by some researchers (Joseph et al., 1990: 1), Eurocentrism evolved through the process of colonialism and economic exploitations and subsequently creating ideological justifications for the colonisation and domination. In other words, imperialism created and used non-Europeans' retrogression and inferiority as an excuse to assert their will and power not only as conquerors, but also as the architect of progress and civilisation, or Europeanising its colonies. Blaut (1993: 2) defined colonialism as '... must mean, for the Africans, Asians, and Americans, not spoilers and cultural destruction but rather the receipt-by-diffusion of European civilisation: modernization."

\section{The History of Malay States And Eurocentrism}

Eurocentrism evolved strongly in Europe, especially Britain in the 19th century and it had affected the average British, including most of the soldiers and colonial administrators sent to Malaya. Clearly instigated from British intervention in Malay states especially Perak since the 1870 s, it was evident that the British were influenced by various ideologies that developed in Europe at that time. Those ideologies included the theory of social evolution and racism that employed the Eurocentric approach to measure the level of civilisation of the indigenous peoples and regarded their inferiority and the greatness of the British as an excuse to intervene and colonise the Malay states one after another, beginning with the state of Perak at the end of the 19th century. In the process of intervention and 'enlightenment', they had produced various official reports and personal accounts which explained not only the potential wealth of the countries they occupied but also about the weaknesses of the political and government systems in those states, often described as backwards, violent and cruel. Most of the records were lodged by British soldiers and administrators who 
had to face the opposition of the Malays especially the Malay ruling elites. As expected, the rulers and the Malay political system were portrayed in an extremely negative manner.

For example, during the intervention in Perak, many British soldiers and administrators had produced records about the Malay political system and the Malay rulers whom they were fighting against, to illustrate the overall 'evil and violent' nature of Malay politics. They claimed that the hostile nature of Malay politics could be found not only in Perak but throughout the Malay states during the 19th century, which was also a true representation of the period before that. They made a comparison of the inferiority of the native political system to the superiority of the European civilisation, with the assumption that the European system was extremely fair, noble and supreme. MacIntyre (1967: 71-72) in his study exemplified various British administrators' reports that suited the nature and purpose of its creation. The reports highlighted a distinct colonial ideology, as well as the elements of that, formed the European views and representations of the natives. Non-European regional political units, including Malaya, in the early period of British colonialism are often seen as 'lawless', 'uncivilised' and 'barbarous'. The typical attitude or views of British colonial administrators regarding the Malays can be explained, for example, from the statement of a British colonial officer in Singapore, 'The innate superiority of the ordinary Englishmen in his sense of honour and justice, is sufficient to dominate the inferior characters of the Malays' or from the words by Hugh Clifford, 'I, the European, the white man, belonging to one of the civilized races in the Old World; The Malays, civilized too, but after the fashion of unchanging Asia, which differs so widely from the restless progressive civilization of the West. '(Quotes by Azmi, 2012: 50-51)

An impression existed of the ultimate state of progress and peace if the Malays, whom were regarded as 'half-children and half-demon', 'semi-civilized' and 'barbaric' are under the domination of the European, especially the great British people. According to Earl of Carnovan, 'It should be our present policy to find and train up some Chief or Chiefs of sufficient capacity and enlightenment to appreciate the advantages of a civilised government and to render some effectual assistance in the government of the country.' The attitude and belief in 'racial superiority' triggered a sense of burden and responsibility among the British colonisers towards the natives to bring them progress and glory. Therefore, Harry Ord expressed the need of a fundamental intervention policy; 'I feel that it would be greatly to the advantage of the settlement if our influence could be thus extended over the Peninsula and I shall not fail to avail myself of any opening that may present itself for doing so.' (Quotes by Azmi, 2012: 51).

As a result of the imperialist thoughts, it was noted that there was a major feature in the colonial reports of the indigenous peoples, namely the dichotomy of the history of the Malay states before and after the British occupation. Prior to the arrival of the British, the Malay states were said to be plagued by terror, feudalism and anarchy. The whole Malay Peninsula, according to Ord, was in the hands of 'the lawless and the turbulent ...', while Frank Swettenham claimed, 'In each state, the ruler whether he was sultan, king, or chief of lower rank, was supreme and absolute. His word was law, and oppression and cruelty were the results.' In the context of the state of Perak before the introduction of British rule, it was said that the government was run using the 'feudal' system, which was barbaric, cruel and despotic Middle Ages. According to William Maxwell, 'The system of government in the various states is despotic. The rulers - whether sultans, rajahs, or what not - have occasionally to fight for their authority ... there was no attempt at a proper administration of justice, simply the strong and wealthy dominated and oppressed the poor and the weak.' The people of Perak before being 'rescued' by the British were claimed to have suffered from slavery, piracy, oppression and anarchy, while its rulers often disputed and fought with each other to seize power. The greedy, wild, savage, and uncivilised traits of the Malay feudal rulers were likened by a British soldier, Captain J. F. McNair as a pirate's behaviour and similar to the bandits on the Rhine River in Germany during the Middle Ages. Under the 'feudal' indigenous rule, it was claimed that there could never be security and safety. What was rampant was oppression, chaos and fear. These situations were the reason to justify the British interference in Perak, as British officials claimed, the British has the responsibility '.. to rescue, if possible, these fertile and productive countries from the ruin which must befall them, if the present disorders continue unchecked.' (Quotes by Azmi, 2012: 52-53)

\section{The Impact of Eurocentrism On Historical Thoughts Of Malay Politics}

The impact of Eurocentrism on the understanding of the Malays or Malay state is very significant. Even the present history of the Malay states to date is in the form of Eurocentric history which is very distinct in nature. The influence of Eurocentrism can be detected through the overwhelming dependence of historians on Western historical concepts that emerged during the colonial times. The borrowed concepts gave a negative picture of the Malay political system because the concepts of the European past were deemed sufficient enough for a retrogressive society and inferior civilisation compared to superior civilisation like Europe. It is not an exaggeration to claim that historians in Malaysia 
until now are simply interested in borrowing the concepts of the European history without trying to build their own concepts of local history based on the values and the comprehensiveness of the Malay political characteristics. The dependence on European concepts derived from Eurocentrism has created many misconceptions about the Malay political features. These misconceptions have deterred historians and scholars in various other areas from studying, researching and making more concise and accurate conclusions about the nature, the practice and the local political knowledge of the early indigenous peoples.

By borrowing the negative European concepts, scholars in Malaysia have indirectly made comparisons between the inferiority of the indigenous people against the superiority of the European civilisation. For example, researchers have fully utilised the concept of ' rulers with absolute rule' (absolutism) and feudalism to explain the practices and political systems of the locals from the time of Malacca to the 19th-century British colonialism. The concept of absolute power, arising from the historiography of the 18th-century European politics and political rule of government, for example, France under the reign of Le Roil Soleil Louis XIV, was used to illustrate the absolute power, the rule of a despotic and cruel Malay government against his subordinates. The absolute monarchy concept, criticised by European thinkers as an oppressive and outdated system, was widely believed had been practised in Malay political traditions since the time of the Malay Sultanate of Malacca. Historians tended to claim that the Malay rulers who ruled Malacca and the Malay states until the 19th century ruled with absolute iron claws such that their tyranny and injustice were not to be questioned by the people who were forced to obediently and blindly obey the rulers.

Similarly, the Malay political system was also claimed to be feudalistic. In this context, the intended feudalism is as mundane and oppressive as the Medieval or Middle Ages system, which saw royal rulers gaining full control of the economy by deploying and enslaving the subordinates; that the king and the ruling classes were two institutions that continuously feud with each other for power, thus creating the state of anarchy, civil war and the collapse of the Malay states. The disunity led to the British intervention who allegedly tried to protect the states or the people from the devastation and violence of 'feudalism' that took place. The historical concepts above, simply taking just a few examples, Asiatic, despotic, absolute monarchy and feudalism, are the creation of the Eurocentric thinking which tried to evaluate the political system and government of the Malay states plagued the backwards and outdated European past practices. It did not emerge from an in-depth study of Malay political practices, but only through assumptions and myths aimed merely at elevating Europe and degrading, even insulting, the Malays. At the same time, the negative European concepts were widely used as a tool to justify British colonialism in the Malay states. For example, the political split and the turmoil caused by 'feudalism' in Perak was the reason used to humanise British colonialism in Perak and other Malay states at the end of the 19th century (Azmi, 2010).

But the colonial concepts had finally been accepted, regarded as true and further developed by local historians who were critical of the Malay political institutions and were influenced by Eurocentrism. Of the local scholars who conveyed the concept of absolute powers included Muhammad Yusoff Hashim and Zainal Abidin Wahid to various scholars from various fields who developed the concept of 'Malay feudalism' - Kassim Ahmad, Syed Hussien Alatas, Chandra Muzafar, Syed Husin Ali and Cheah Boong Kheng - all of them in their respective writings tried to portray the misconducts of the Malay political system as featured in the colonial era. What is most prominent is the historical outlook set by Syed Hussein Alatas, famous for his The Myth of Lazy Native book. After strongly criticising the colonial myths about the lazy natives and Raffles' outlook about colonialism that he believed racist in nature (Alatas 1972, 1977), Syed Hussein himself developed the concept of 'Malay feudalism' that was initially introduced in the colonial writings which contained the concept of the lazy indigenous people itself.

Therefore, this brief study wanted to clarify that the concepts and historical interpretations of the early Malay political system and practice are largely, if not entirely, dominated by a form of negative and contemplative Eurocentric thinking or Eurocentrism. Hence, the interpretation of the early Malay political history has to be reshaped and revisited, by reflecting on some of the major shortcomings inherent in today's interpretation, and by taking into account the local knowledge and values that the indigenous people truly held. It is also time for local historians to build their own historical concepts that are consistent with local historical values and far from the Eurocentric influence and the creation of negative images created for the purpose of justifying colonialism. The concept of an absolute ruling monarchy never existed and was unsuitable for explaining the Malay political traits and Malay government, which was never created based on the ruler's absolute power and the absolute loyalty of the people towards its rulers. In the history of the Malays, incidents of rulers or the ruling class being disputed, even murdered, are common phenomena that had occurred since the time of Malacca Sultanate, although it cannot be detected in the European political practice during the same period. 
The Malay rulers in the 19th century were also not absolute rulers with wealth and massive soldiers like King John of England or King Louis XIV of France who needed to fight and compete with his nobles to strengthen his rule. The rulers ruled with the support of the ruling class, and the relationships between them was usually very close. Their relationships, as depicted in the texts of traditional Malay historiography, such as in Misa Melayu, is likened to a government in an ark. The King would be unable to lead the ark without the cooperation of the ruling class, and therefore, the King had to channel certain powers to his ministers in accordance with his role in a government. The King did not make his own decisions in matters involving government policy, for example in diplomatic or warfare relations, as every decision was taken with the advice and consent of his principal advisors or ministers. This clarified that there was no concept of the absolute royal rule in the Malay states. The leadership of the Malay states as depicted in Malay literature is based on practice or consensus, not based on the enforcement of power and despotic rule. It can also be explained that the values of 'democracy' are not strange in Malay political practice, as opposed to the claimed made by the colonial sources (Andaya, 1975).

The Malay monarchy in Melaka in the 15th century as well as in Perak in the 19th century were not similar to the feudalistic-aristocrats in Western Europe Middle Ages who needed to compete or challenge their king to gain power and liberate themselves. On the other hand, the relationships between the King and the Malay ruling class were very close, they complement each other, and the Malay sultanate was united because the king cannot rule unaided while the ruling class do not have the power or followers. There is no evidence in history that can prove that the ruling class or advisors, driven by strong fortitude that they obtained through their wealth and many followers, were able to challenge a Sultan and compete for his sovereignty even if a weak or poor Sultan reigns. This is because the principle of the relationship between the King and the Malay ruling class was not built based on a feudalistic relationship, but based on a strong bond and relationships between them. This is the reason why a harmonious relationship existed between the government in the palace and his advisors before the intervention of the colonial power.

The close and harmonious relationship between the ruling class explained why governmental monarchy in the Malay states generally ruled well and allowed prosperity to be achieved, thereby preventing widespread oppression and injustice of power. Although it was often stressed that early Malay political institutions were so oppressive and cruel to the subordinates, it was merely assertions and accusations that were deliberately created by the British to justify their intervention in the Malay states in the name of upholding the security and justice in those states. But in reality, the states were in a state of peace, prosperity, and stability until they became fractured and became uncontrolled as a result of foreign interventions that deeply interfered in the Malay political system to create chaos and disorders.

\section{Conclusion}

In general, it can be said that there are widespread misunderstandings about the political system found in the Malay states before and during the era of British colonialism. This was largely due to the strong influence of Eurocentric thoughts on the idea of imperialism which had encouraged negative records of the history of the Malay political system. The Eurocentric thoughts which became the backbone of the formation of myths about the crimes and the destruction of the native's political system caused by prejudices, rather than scientific studies about inferiority and indigenous crimes that were never supported by clear evidence. The portrayal in the colonial record that the relationship between the rulers and the people in the Malay states was in the form of conflict before the colonial period of the British and the devastating civil war and widespread oppression that ensued were inaccurate and lacked fairness. They were deliberately enlivened and questionable forms of deceptions. Negative European intangible concepts such as absolute and feudal rulers do not exist except in the form of prejudice and bias portrayed by colonial administrators aimed at lowering the Malay political system and establishing the justification for colonialism in the Malay states.

What is clear, the political system and the Malay sultanate institutions have been so systematic, harmonious, effective and capable of meeting the goals of the government and government in accordance with the values, knowledge and needs of the indigenous peoples. Feudalism and the rule of the king with absolute power was a foreign practice that only existed in European political practice but had never appeared to be the actual political practice of the indigenous Malay community as was often claimed. Conflicts, civil wars, massive oppression and the collapse of the Malay state allegedly resulting from 'Malay feudalism' were also myths that had never existed, but intentionally created and exaggerated to justify British intervention in the Malay states which are accused as backwards and oppressed. 


\section{Acknowledgment}

The author would like to sincerely thank Universiti Sains Malaysia for funding this research through the research university grants (1001 / PHUMANITI / 816232).

\section{References}

1. Alatas, S. H. Thomas Stamford Raffles 1781-1826: Schemer or Reformer? (London: Angus and Robertson, 1972).

2. Alatas, S.H. The Myth of the Lazy Native: A Study of the Image of the Malays, Filipinos and Javanese from the 16th to the 20th Century and Its Function in the Ideology of Colonial Capitalism (London: Frank Cass, 1977).

3. Amin, Samir. Eurocentrism (trans. Russell Moore) (New York: Monthly Review Press, 1989).

4. Amini, Majid. 'Allegories of Reason: Eurocentrism and Native Philosophical Resistance'. Culture, Theory and Critique 51, 1 (2010).

5. Andaya, B. W. 'The Nature of the State in Eighteenth Century Perak' in Anthony Reid \& Lance Castles (eds.). Pre-Colonial State Systems in Southeast Asia, Monograph No. 6 (Kuala Lumpur: MBRAS, 1975).

6. Azmi Arifin. 'Feudalisme Melayu: Asal-Usul Pemikiran, Sejarah dan Pensejarahan' ('Malay Feudalism': The Origin of Thought, History and Historiography'. Ph.D Thesis, Department of History, Faculty of Social Science and Humanities, Universiti Kebangsaan Malaysia, Malaysia (2007).

7. Azmi Arifin. 'Perak Disturbances 1871-75: British Colonialism, the Chinese Secret Societies and the Malay Rulers.' Jebat: Malaysian Journal of History, Politics and Strategic Studies 39 (2012).

8. Blaut, J. M. The Colonizer's Model of the World: Geographical Diffusionism and Eurocentric History (New York: The Guilford Press, 1993).

9. Blaut, J. M. Eight Eurocentric Historians (New York: The Guilford Press, 2000).

10. Clifford, Hugh 1875. 'Life in the Malay Peninsula: As it was and is' in Paul H. Kratoska (ed.). Honourable Intentions: Talks on the British Empire in South-East Asia Delivered at the Royal Colonial Institute 1874-1928 (Singapore: Oxford University Press, 1983).

11. Forstater, M. 'Pan African and Afro-Asian Alternatives (to) and Critiques (of Eurocentrism)' in Kanth, R. K. (ed). The Challenge of Eurocentrism: Global Perspectives, Policy and Prospects (New York: Palgrave Macmillan, 2009).

12. Goh, D. P. 'Imperialism and "Medieval" Natives: The Malay Image in Anglo-American Travalogues and Colonialism in Malaya and the Philiphines'. International Journal of Cultural Studies 1, 3 (2007).

13. Hobson, J. M. 'What have the Muslims ever done for us? Islamic Origins of Western Civilization' in Kanth, R. K. (ed). The Challenge of Eurocentrism: Global Perspectives, Policy and Prospects (New York: Palgrave Macmillan. 2009).

14. Joseph, George G., Reddy, Vasu dan Searle-Chatterjee, Mary 'Eurocentrism in the Social Science.' Race and Class 31, 4 (1990).

15. Lander, E. 'Eurocentrism and Colonialism in Latin America Social Thought'. Nepantla: Views From South 1, 3 (2000).

16. Marshall, P. J. \& Williams, Glyndwr. The Great Map of Mankind: British Perceptions of the World in the Age of Enlightenment (London: J. M. Dent \& Sons, 1982).

17. McIntyre, W. D. The Imperial Frontier in the Tropics, 1865-1873 (New York: St. Martins, 1967).

18. Miles, Robert. Racism (London: Routledge, 1989).

19. Quijano, A. \& Ennis, M. 'Coloniality of Power, Eurocenrism and Latin America.' Nepantla: Views From South 1, 3 (2000).

20. S. Sayyid. 'Islam (ism), Eurocentrism and the World Order'. Defence Studies 7, 3 (2007).

21. Savage, V. R. Western Impressions of Nature and Landscape in Southeast Asia (Singapore: National University of Singapore, 1984).

22. Steadman, J. M. The Myth of Asia (London: Macmillan, 1969).

23. Tregonning, K. G. 'A New Approach to Malaysia History: Look at Our Story From Inside, Not From Outside'. The Straits Times, 24 November (1958). 